UNITED STATES DEPARTMENT OF THE INTERIOR

GEOLOGICAL SURVEY

\title{
Quartz-molybdenite veins in the Priestly Lake granodiorite, north-central Maine
}

by

Robert A. Ayuso $1 /$ and Stephen G. Shank $1 /$

Open File Report $83-800$

This report is preliminary and has not been reviewed for conformity with U.S. Geological Survey editorial standards and stratiraphic nonmenclature.

1/ U. S. Geological Survey, Reston, Virginia 


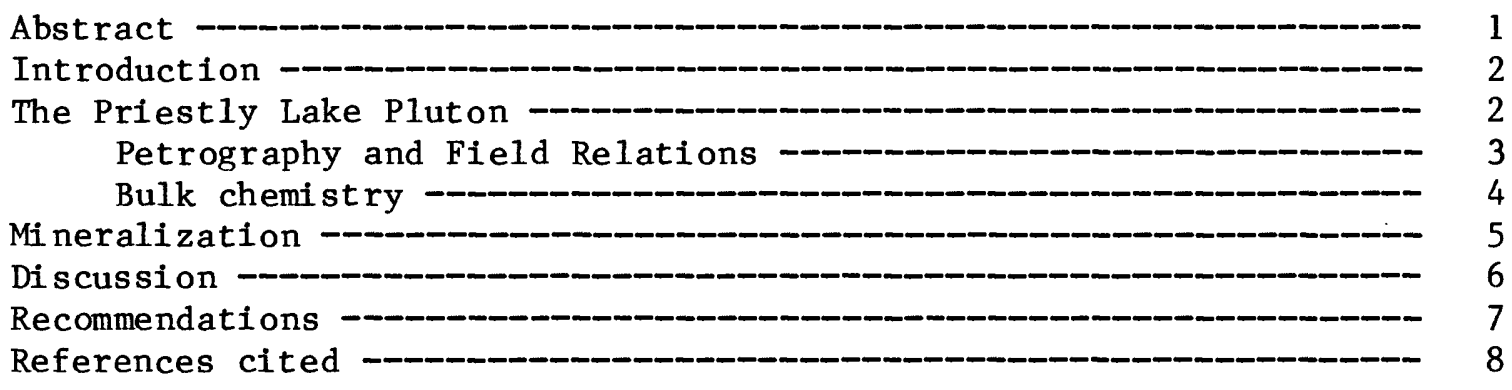

\section{ILLUSTRATIONS}

Figure 1.-- Location map showing the Priestly Lake pluton and generalized area containing quartz-molybdenite veins

Figure 2.-- Harker variation diagrams for the Priestly Lake pluton

\section{TABLES}

Table 1.-- Preliminary major element analyses of rocks from the Priestly Lake pluton, Maine

Table 2.-- Preliminary trace element abundances and ranges (in ppm) of rocks from the Priestly Lake pluton, Maine -

\section{FIGURE CAPTIONS}

Figure 1.-- Location of the Priestly Lake pluton in north-central Maine

Figure 2.-- Harker variation diagrams of the Priestly Lake pluton. (A11 values are in weight per cent.) 
Quartz-molybdenite veins up to $15 \mathrm{~cm}$ in width occur in fine to mediumgrained porphyritic biotite-hornblende granodiorite at Priestly Lake, north-central Maine. An area of about $150 \mathrm{~m} \times 150 \mathrm{~m}$ contains quartzmolybdenite veins; a larger area is characterized by barren quartz veins. Quartz-molybdenite veins are concentrated within the most felsic variants of the intrusion as suggested by lower mafic mineral contents. The pluton has a narrow range in $\mathrm{SiO}_{2}$ (67-70 wt.\%), major oxides, and in trace-element compositions.

Molybdenite occurs as coarse grained clusters in pockets within the quartz veins, and fills fractures in the quartz veins and host rocks. Disseminated molybdenite in the granodiorite is relatively rare and ocurrs only in the area characterized by a high density of quartz veins (up to 50 veins per square meter). Alteration envelopes along the quartz veins are very thin or absent, although in some areas the granodiorite appears to be selectively and pervasively altered. Sericite, chlorite, epidote, calcite, pyrite, and quartz are concentrated near the quartzmolybdenite veins.

Many of the field and geochemical characteristics of the Priestly Lake pluton are unlike those of major molybdenum-producing areas (Climax, Henderson, Urad). For example, the area of alteration seems to be of limited extent, the host rock is not intensely altered hydrothermally at the surface, the density of fractures is rather low in the mineralized area, and the amount of disseminated molybdenite appears to be small. However, the Priestly Lake pluton may be a small fraction of a concealed batholith as suggested by geophysical data. It is conceivable that the type of mineralization at the surface might be the expression of more extensive molybdenite mineralization at depth.

The quartz-molybdenite veins in the Priestly Lake pluton are significant because they indicate that potential molybdenum sources for producing mineralized granites were available at depth. Future studies should be aimed at delineating the area of quartz-molybdenite mineralization, documenting hydrothermal alteration and zonation, determining fracture density, and evaluating the sulfide assemblage. 
This report is a preliminary summary of a field study conducted for the U.S. Geological Survey by R. A. Ayuso and assistants B. Ward (1982) and S. G. Shank (1983). The objective of this report is to document the occurrence and the potential importance of quartz-molybdenite veins in the Priestly Lake pluton. More detailed studies that are now in progress deal with the petrology, geochemistry (bulk composition and isotopes), and radiometric age determinations.

The Priestly Lake pluton is located approximately $72 \mathrm{~km}$ ( 45 miles) west of the town of Ashland, in the thickly forested region near the Allagash Wilderness Waterway in northern Maine (Fig. 1). Privately-owned logging roads are the only means of access. Relief within the Priestly Lake pluton is up to 800 feet. Most of the granitic outcrops are located in the Priestly Mountain area where elevations range from 1130 to 1900 feet.

The Priestly Lake pluton intrudes low grade metasedimentary rocks of the Seboomook Formation which consist mostly of shales, quartzites and graywackes. Reconaissance mapping by Boudette and others (1976) indicated that the Seboomook Formation is of Early Devonian age.

\section{The Priestly Lake Pluton}

The granitic stock at Priestly Lake is sporadically exposed along the eastern flank of Priestly Mountain, and is relatively unexposed in the area between Umsaskis Lake and Priestly Lake (Fig. 1). Boudette and others (1976) interpreted the gravity data of Kane and Bromery (1966) as suggesting that the pluton may underlie the Seboomook Formation east of Priestly Lake at a shallow depth. Although the exposed area of the stock is small $\left(6-8 \mathrm{~km}^{2}\right)$, the shallow dip of the eastern contact is suggested by the many granodiorite dikes which intrude country rock and indicate that the stock may represent a cupola of a much larger intrusion (Boudette and others, 1976). 
Most of the exposed Priestly Lake stock is composed of the medium to coarse grained, hornblende-biotite granodiorite, but in the vicinity of Priestly Mountain, a finer grained porphyritic variety dominates. Existing field data do not allow for precise determination of the extent of each rock type. Both varieties are gray in field appearance. The essential mineralogy of both textural types includes plagioclase, alkali feldspar, quartz, biotite and amphibole. The accessory suite contains apatite, zi rcon, sphene, and allanite. Opaque minerals include ilmenite, magnetite and rare sulfide (pyrite) that are randomly but sparingly distributed. Primary muscovite, andalusite, and other aluminous minerals are absent in the pluton. The average modal composition of the Priestly Lake pluton is: $25 \%$ quartz, $12 \%$ alkali feldspar, $48 \%$ plagioclase, $9 \%$ biotite, and $5 \%$ hornblende. Secondary minerals occur in trace amounts and include sericite (replacing the majority of the plagioclase cores), chlorite (replacing hornblende and biotite), epidote (replacing the mafic minerals), and iron oxides (replacing mafic and oxide minerals).

One of the most important petrographic characteristics of the Priestly Lake pluton is the interrelation of the mafic minerals. Hornblende and biotite are typically intergrown, and in many cases the intergrowths suggest that biotite preceded hornblende in the crystallization sequence. Euhedral biotite forming pseudohexagonal plates up to $0.5 \mathrm{~cm}$ in diameter is especially abundant in the finer grained, moderately porphyritic granodiorite. Biotite is significantly more abundant than hornblende in the finer grained granodiorite. The total abundance of mafic minerals is also lower in the finer grained granodiorite compared to the medium grained granodiorite. clusters of mafic minerals (mafic inclusions) are relatively more numerous in the medium to coarse-grained granodiorite, where they range in size from a few centimeters to as much as $10 \mathrm{~cm}$.

Alkali feldspar is the predominant phenocryst in the Priestly Lake pluton. In the finer-grained granodiorite, quartz also forms euhedral microphenocrysts. Plagioclase is generally subhedral, shows albite twinning, and is strongly zoned (optically) from core to rim. Inclusions of amphibole, biotite, accessories, and opaques are locally present near the cores of the plagioclase grains. Amphibole forms poikilitic grains enclosing randomly oriented biotite laths. Subhedral to anhedral shapes of amphibole at plagioclase-amphibole grain contacts also suggest that amphibole might have crystallized contemporaneously with plagioclase.

Petrographic studies have outlined a general crystallization sequence for the minerals in the Priestly Lake pluton. The order of crystallization may be generalized as follows: the accessory suite including allanite, apatite, zircon, sphene and the opaques precipitated first, followed by biotite, amphibole, and plagioclase. Quartz and alkali feldspar are mutually intergrown or share irregular faces suggesting that they coprecipitated near the end of the crystallization sequence. 


\section{Bulk Chemistry}

The range in bulk composition of the granodiorite at Priestly Lake is relatively narrow. Preliminary analyses on unaltered samples primarily from the medium- to coarse-grained granodiorite (Table 1) suggest that the total variation in $\mathrm{SiO}_{2}$ is from about 67 weight percent (wt.\%) to 70 wt.\%. The variation in $\mathrm{Al}_{2} \mathrm{O}_{3}$ is from 14.8 to $17.9 \mathrm{wt} . \%$, that of $\mathrm{TiO}_{2}$ from 0.4 to $0.5 \mathrm{wt} . \%, \mathrm{Fe}_{2} \mathrm{O}_{3}$ from 2.9 to $3.4 \mathrm{wt} . \%$, MgO from 0.9 to $1.4 \mathrm{wt} . \%$, MnO from 0.04 to 0.06 wt.\%, $\mathrm{CaO}$ from 2.8 to 3.4 wt.\%, $\mathrm{Na}_{2} \mathrm{O}$ from 3.8 to 4.1 wt.\%, and $\mathrm{K}_{2} \mathrm{O}$ from 2.4 to 2.9 wt.\% (Table 1 ). $\mathrm{Al}_{2} \mathrm{O}_{3}, \mathrm{TiO}_{2}, \mathrm{Fe}_{2} \mathrm{O}_{3}, \mathrm{MgO}$, and $\mathrm{CaO}$ show broad, inversely correlated compositional changes as a function of $\mathrm{SiO}_{2}$ (Fig. 2). All other oxides exhibit limited variations, uncorrelated with increasing $\mathrm{SiO}_{2} \cdot \mathrm{F}$ and $\mathrm{Cl}$ are generally less than 0.05 and 0.029 wt. $\%$, respectively.

The Priestly Lake pluton seems to be a homogeneous stock as suggested by the moderate lithological differences in the field, and by the similarity of data for major oxides (Fig. 2). This lack of bulk-chemical variation is also evident for most of the trace elements, although $\mathrm{Sr}$ has a range from 260 to $305 \mathrm{ppm}$ (Table 2). Positive correlation of $\mathrm{Sr}$ with Ba is as expected for calcalkaline plutons, but $\mathrm{Sr}$ is not correlated with $\mathrm{Rb}$ at Priestly Lake. Similarly, the high valence cations ( $\mathrm{Ta}, \mathrm{Nb}, \mathrm{Hf}, \mathrm{Zr}$, Th, J) do not exhibit regular and consistent variations among themselves or with $\mathrm{SiO}_{2}, \mathrm{~F}$, or $\mathrm{Cl}$. The high-valence cations show a positive correlation of $\mathrm{Nb}$ with $\mathrm{Ta}, \mathrm{Zr}$, and $\mathrm{U}$; $\mathrm{Nb}$ is also correlated with $\mathrm{Cs}$ and $\mathrm{Sc}$ (Table 2). However, $\mathrm{Nb}$ is not correlated with Mo, W, or Li and thus cannot be used to monitor the geochemical evolution of the pluton and the formation of the quartz-molybdenite veins.

The bulk chemical data for the Priestly Lake pluton show major compositional differences with granite plutons associated with significant molybdenum mi neralization (granite-molybdenite systems). However, compared to the compositions of granodiorite-molybdenite systems compiled by Mutschler and others (1981), unaltered samples from the Priestly Lake pluton are higher in $\mathrm{TiO}_{2}$ but are broadly comparable in the major oxides. Molybdenite mineralization at Priestly Lake is associated with less felsic and less silicieous rocks than the granite-molybdenite systems of the Climax-type (White and others, 1981). The host rocks at Henderson, Mount Emmons, and Questa (Mutschler and others, 1981) are also more felsic and silicieous than the rocks at Priestly Lake. The Priestly Lake pluton is also less felsic and silicieous than the molybdenum-bearing plutons recently discovered in Alaska at Quartz Hill (Hudson and others, 1979), and Ketchikan (Hudson and others, 1981). 
Trace-element compositions strongly suggest critical differences between the Priestly Lake granodiorite and other molybdenite-bearing plutons. For example, the average $\mathrm{Sr}$ concentration is $283 \mathrm{ppm}$, significantly higher than for rocks from the Quartz Hill deposit (78 ppm) and most rocks from Climax. The Priestly Lake granodiorite is also unlike other mi neralized molybdenum plutons because of its low concentrations of $\mathrm{Rb}, \mathrm{Be}, \mathrm{Nb}$, and $\mathrm{Li}$, and its high concentrations of $\mathrm{Ba}, \mathrm{Sc}$, and $\mathrm{Zr}$. More importantly, the value of Mo in the unmineralized hornblende-biotite granodiorite is ext remely low, averaging only $0.8 \mathrm{ppm}$. This value is similar to that of the Quartz Hill deposit where the unmineralized host rocks have $<2.2 \mathrm{ppm}$ Mo. Both of these areas contrast with quartz-molybdenite-pyrite stockworks at South Park (New Mexico), where Mo is $>15 \mathrm{ppm}$ in the host granite (Ludington, 1981). The abundance of $\mathrm{W}$ in the Priestly Lake pluton is anomalously high in comparison to typically unmineralized rocks.

\section{Mineralization}

Quartz-molybdenite veins occur along the east-facing flank of Priestly Mountain, between the fire tower and Priestly Lake (Fig. 1). In an area of $150 \mathrm{~m}$ by $150 \mathrm{~m}$, quartz veins range in width from millimeters to about $15 \mathrm{~cm}$ and invariably contain molybdenite. The density of quartz-molybdenite veins in this area probably ranges from 50 veins per square meter to 5 veins per square meter, although most commonly the density may be about 5 to 10 veins per $\mathrm{m}^{2}$. Although the quartz-molybdenite veins show a wide range of attitudes, many are aligned about a trend of $\mathrm{N} 80^{\circ} \mathrm{W}$.

The mineral assemblage in the veins consists of quartz + molybdenite \pm pyrite and epidote (?). Leafy aggregates of coarse molybdenite grains about $4 \mathrm{~mm}$ in diameter form clusters (up to $3 \mathrm{~cm}$ ) and thin selvages filling internal fractures in the quartz veins and in the granodiorite. In addition to the molybdenite and quartz, both the host (fine- to mediumgrained granodiorite) and the quartz veins have numerous rusty spots. Molybdenite clusters are commonly rimmed by the rusty spots. Small molybdenite clusters, or grains also occur disseminated in the porphyritic biotite granodiorite. Disseminated molybdenite appears to be relatively rare, however, and seems to occur only in the area with abundant quartzmolybdenite veins.

Quartz-molybdenite veins are white to gray, have a greasy appearance, and are commonly criss-crossed by fractures. Many of these fractures continue through the host rock where they are sparsely mineralized. Some of the fractures in the granodiorite are filled by fine-grained molybdenite and contain little or no quartz. The host rock for these fractures typically has no evidence of alteration adjacent to the veins. 
Granodiorite near the quartz-molybdenite veins is not strongly altered. Most of the veins are lined by thin (1-2 mm) alteration envelopes or show no evidence of alteration along the contacts with the host rock. Plagioclase adjacent to the veins is intensely sericitized. Fine-grained sericite together with some larger plates (muscovite) indicate that this alteration is selectively pervasive. Sericite is not commonly disseminated outside of the plagioclase grains, however. Calcite replaces plagioclase and it occurs also near altered biotite grains.

Most biotite grains near the contact with the quartz-molybdenite veins are chloritized, resulting in leafy intergrowths of green chlorite and brownish biotite. Hornblende is relatively rare, but where present is also chloritized. Hematite commonly envelops the mafic minerals. Epidote also occurs with the altered plagioclase and in the biotite plates.

Quartz-molybdenite veins are less abundant in the area to the north, along Priestly Mountain. However, rusty quartz veins showing similar ranges in size and density occur for about $1 \mathrm{~km}$ north between Priestly Lake and Priestly Mountain. As in the region characterized by quartzmolybdenite veins, rusty quartz veins show a wide variation in density.

\section{Discussion}

Preliminary field studies indicate that the Priestly Lake pluton is cut by a stockwork of quartz-molybdenite veins. The exposed part of the pluton might reflect the cupola of a much larger batholith, and thus it is face represents the fringes of a more significantly altered system at depth. Quartz-molybdenite veins not associated with strong alteration may have been the product of the waning stages of a hydrothermal system. If this is true, the quartz-molybdenite veins at Priestly Lake may be the surface reflection of a molybdenum-rich system, and may indicate that higher grades of mineralization associated with an alteration envelope exist at depth. Subsequent mobilization of molybdenum in the near-surface area of Priestly Lake probably occurred in pulses as suggested by the quartz-molybdenite veins, and subsequently by fractures seemingly filled only by molybdenite.

The total mineralized area at Priestly Lake is unknown, but out field studies suggest that it is of limited extent. Although the quartzmolybdenite veins may extend considerably at depth, or laterally under the glacial debris, they have produced very little alteration of the host porphyritic granodiorite. This suggests a lack of an alteration system commonly associated with low grade, high-tonnage porphyry molybdenum deposits. If the quartz-molybdenite veins do not represent high temperature alteration from a hydrothermal system, then the probability of finding economically significant grades is low. 
The occurrence of previously unreported quartz-molybdenite veins in the Priestly Lake pluton is important because it indicates the possibility of significant mineralization at depth. Although the veins appear not to be associated with a pervasive hydrothermal alteration zone, they may represent the upper, outer extensions of an alteration zone below surface exposures. Determination of the full extent of the area containing quartz-molybdenite veins is of primary importance in future studies. Petrographic investigations aimed at establishing the presence of alteration zones, detailed chip sampling for geochemistry, determining the preferred orientation of fractures and abundance of the sulfide minerals might also prove critical in evaluating the economic importance of this occurrence. 
Boudette, E. L., Hatch, N. L. Jr., and Harwood, D. S., 1976, Reconnaissance geology of the Upper St. John and Allagash River basins, Maine: U.S. Geo1. Survey Bu11. 1406, 37 p.

Hudson, T., Arth, J. G., and Muth, K. G., 1981, Geochemistry of intrusive rocks associated with molybdenite deposits, Ketchikan quadrangle, southeastern Alaska: Econ. Geo1., v. 76, no. 5, p. 1225-1232.

Hudson, T., Smith, J. G., and Elliott., R. L., 1979, Petrology, composition, and age of intrusive rocks associated with the Quartz Hill molybdenite deposit, southeastern Alaska: Can. J. Earth Sci. v. 16, p. 1805-1822.

Kane, M. F., and Bromery, R. W., 1966, Simple Bouguer gravity map of Maine: U.S. Geol. Survey Geophys. Inv. Map GP-580.

Ludington, S., 1981, Quartz-pyrite-molybdenite stockwork near South Fork Peak, Taos County, New Mexico: U.S. Geol. Survey Open-File Report 81-1080, 8 p.

Mutschler, F. E., Wright, E. G., Ludington, S., and Abbott, J. T., 1981, Granite-molybdenite systems: Econ. Geol., v. 76, p. 874-897.

White, W. H., Brookstrom, A. A., Kamilli, R. J., Ganster, M. W., Smith, R. P., Ranta, D. E., and Steininger, R. C., 1981, Character and origin of Climaxtype molybdenum deposits: Econ. Geol., 75th Ann. Vo1., p. 270-316. 


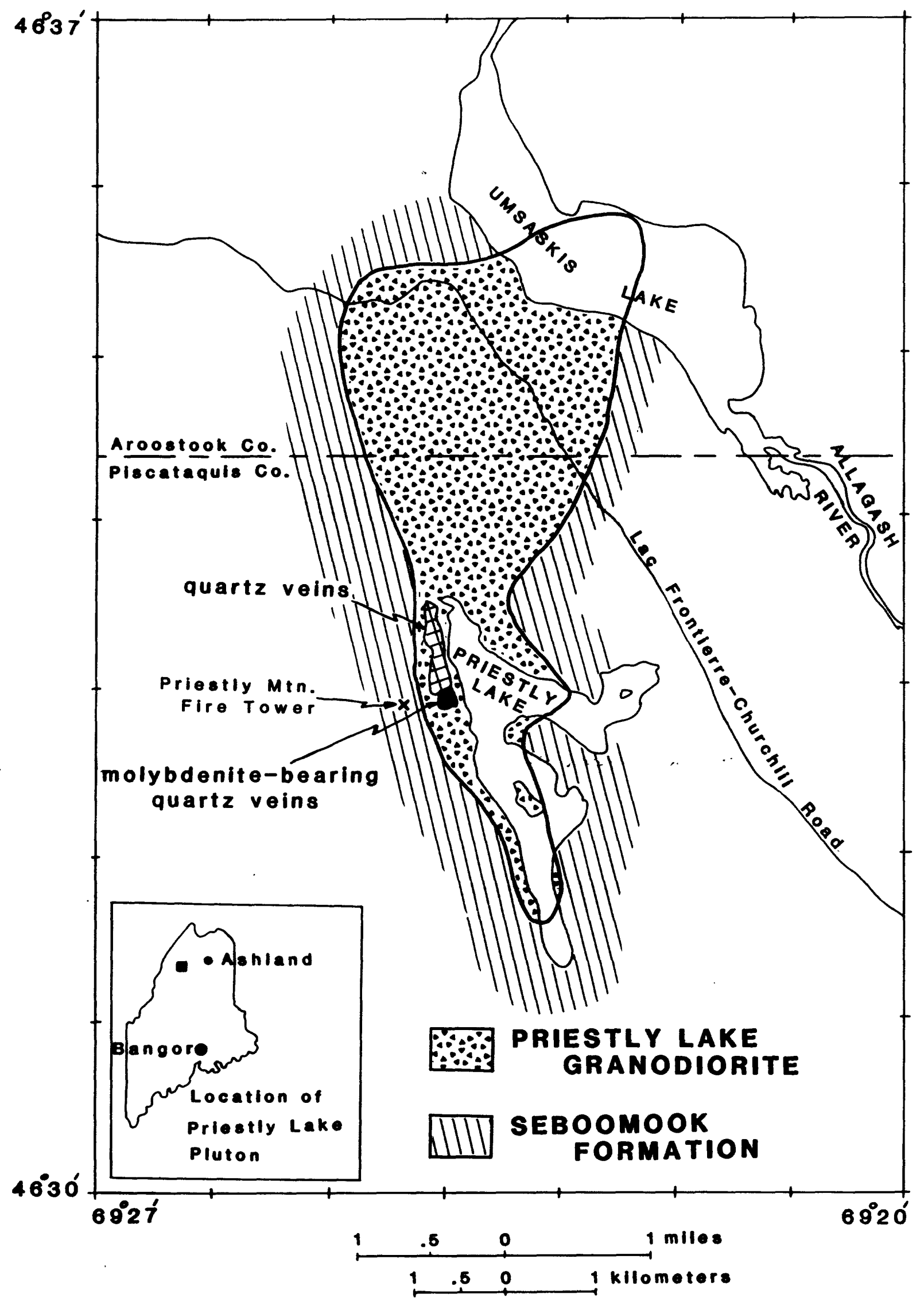

Figure 1

Geology by R. A. Ayuso and assistants B. Ward (1982) and S. Shank (1983); modified from the reconnaissance mapping by Boudette and others (1976). 


\section{PRIESTLY LAKE PLUTON}

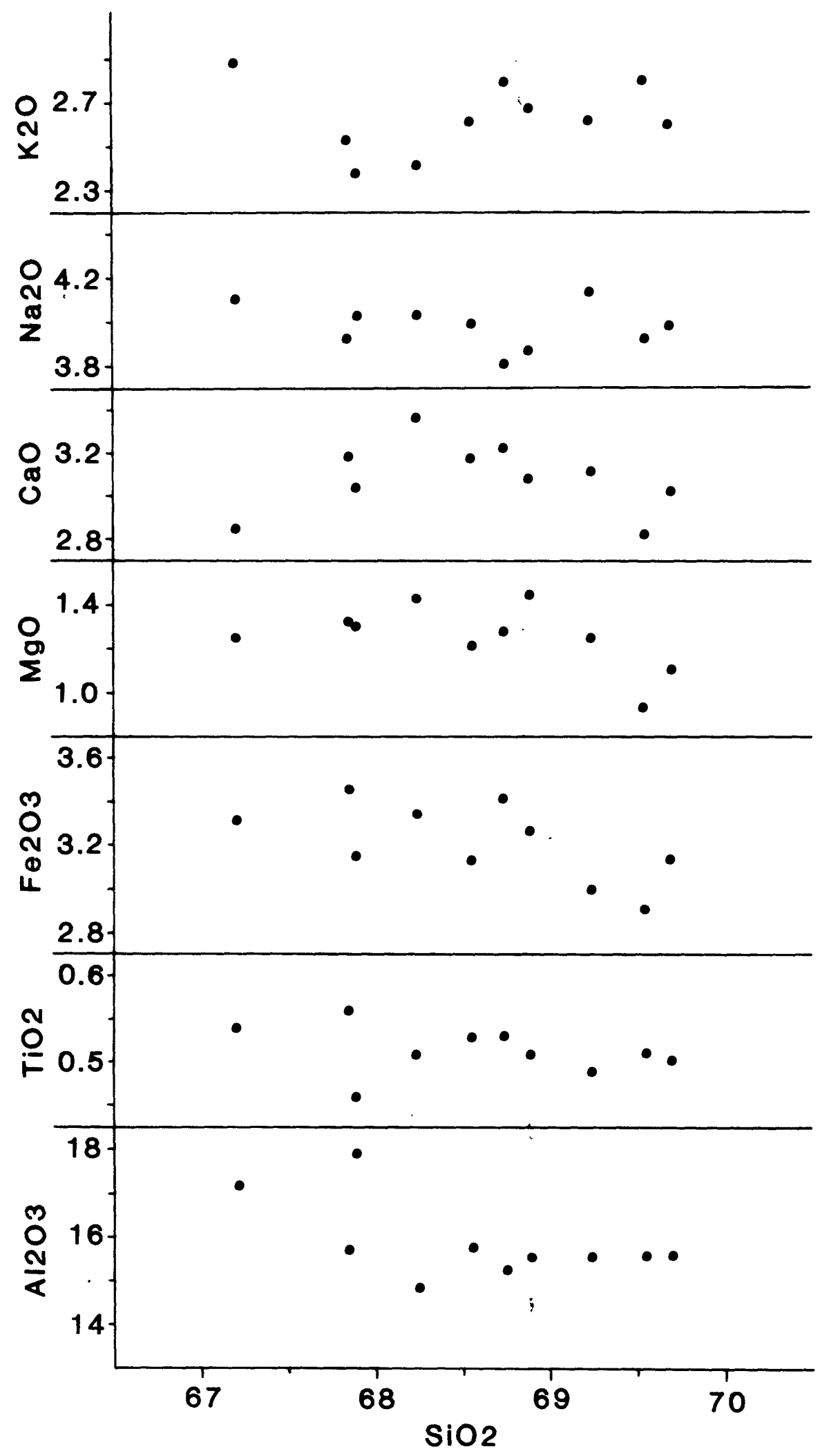

Figure 2 


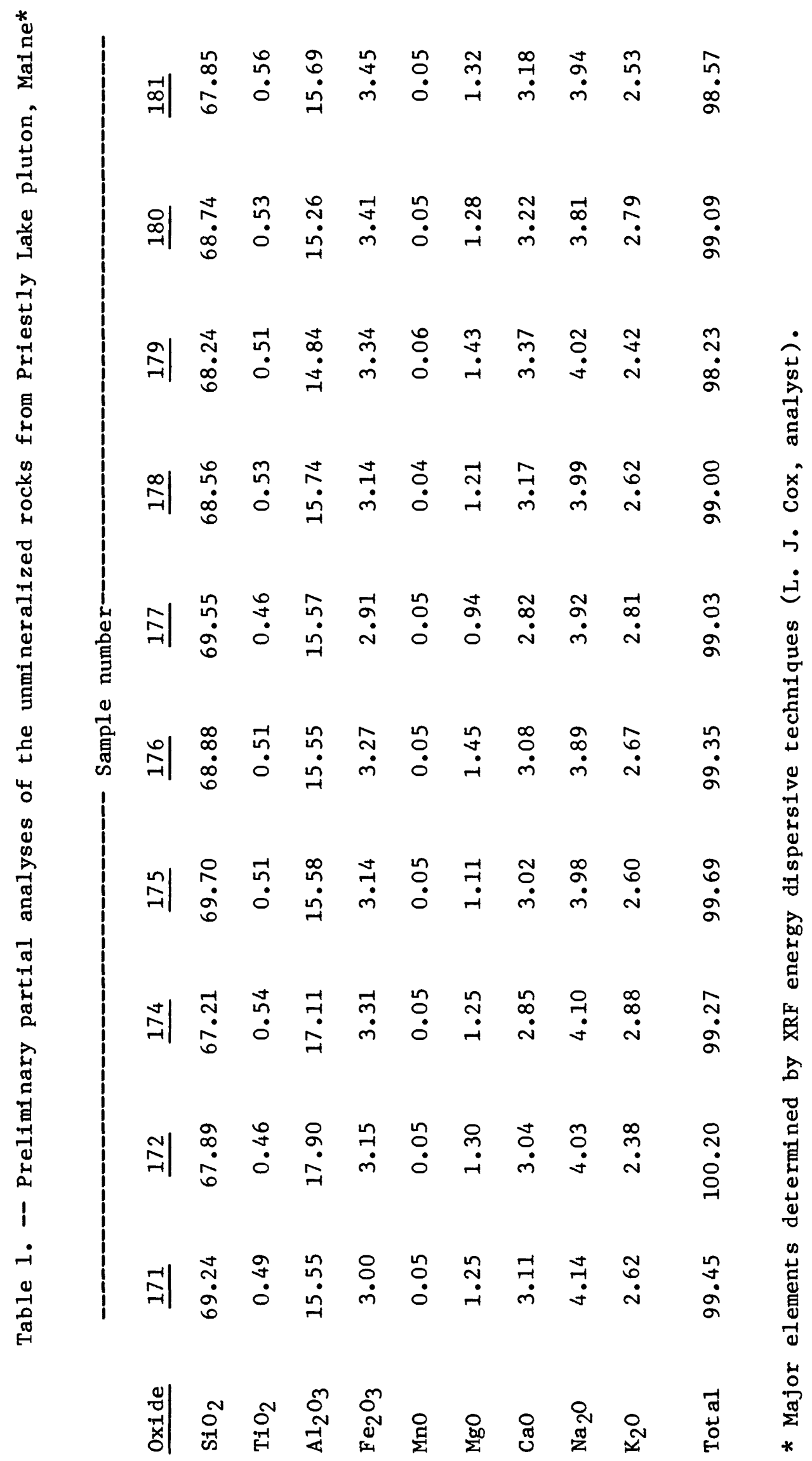


Table 2.-- Selected trace-element abundances (ppm) for representative unmineralized samples of the Priestly Lake pluton, Maine.*

\begin{tabular}{lll} 
Element & Average & Range \\
\cline { 2 - 3 } $\mathrm{Rb}$ & 107 & $95-123$ \\
$\mathrm{Sr}$ & 283 & $264-306$ \\
$\mathrm{Ba}$ & 622 & $544-797$ \\
$\mathrm{Cs}$ & 1.9 & $1.4-2.7$ \\
$\mathrm{Th}$ & 14 & $12-17$ \\
$\mathrm{U}$ & 2 & $1-3$ \\
$\mathrm{Zr}$ & 190 & $147-222$ \\
$\mathrm{Hf}$ & 4.8 & $4.1-5.3$ \\
$\mathrm{Ta}$ & 0.95 & $0.7-1.2$ \\
$\mathrm{Nb}$ & 9.8 & $8.6-12.6$ \\
$\mathrm{Li}$ & 21.2 & $18-29$ \\
$\mathrm{~B}$ & 2 & $0.6-3.4$ \\
$\mathrm{Be}$ & 1.7 & $1.5-2.9$ \\
$\mathrm{Mo}$ & 0.8 & $0.1-3.3$ \\
$\mathrm{~W}$ & 10 & $0.4-68$ \\
$\mathrm{Sn}$ & 1.1 & $0.6-1.7$ \\
$\mathrm{Sc}$ & 1.9 & $5.6-7.6$
\end{tabular}

* Samples were analyzed by Instrumental Neutron Activation Analysis (L. J. Schwarz, analyst), by induction coupled plasma (J. Kane and S. Berman, analysts) and atomic absorption spectroscopy. 